\title{
INTERCULTURAL COMMUNICATION
}

DOI https://doi.org/10.30525/978-9934-588-90-7-72

\section{ВИСОКИЙ РІВЕНЬ ЗАСВОЄННЯ ІНОЗЕМНОЇ МОВИ ЯК ПОКАЗНИК СФОРМОВАНОСТІ ІНШОМОВНОЇ КОМУНІКАТИВНОЇ КУЛЬТУРИ}

\author{
Бреславець Н. О. \\ кандидат педагогічних наук, \\ дочент кафедри іноземних мов за професійним спрямуванням \\ Національний педагогічний університет імені М. П. Драгоманова \\ м. Київ, Украӥна
}

Сучасне людство існує в інформаційному просторі. На даний час, завдяки наявності численних способів і технічних засобів можлива передача різних видів інформації, основною формою якої є вербальна форма, що існує у вигляді усного та писемного мовлення. Процеси передачі інформації носять назву комунікації, а сукупність засобів, призначених для цієї мети, називаються засобами (системами) комунікації. Комунікація являє собою суспільне явище 3 точки зору іiі виникнення, сутності, умов ії розвитку. Цілі комунікації соціальні й схильні до дії суспільства. Комунікативна поведінка - поведінка суспільна. Цим визначається специфіка людської комунікації [3].

Міжкультурна комунікація характеризується здатністю особистості встановлювати взаємовідносини з представниками інших культур, що підвищує загальну культуру фахівця, його конкурентоздатність на міжнародному ринку праці; це й знання про всі сфери життя країни, мова якої вивчається, і виховання шанобливого ставлення до країни і народу, i розвиток мовних, мовленнєвих та інших здібностей, i формування вміння спілкуватися у різних життєвих ситуаціях, і формування мотивації до подальшого оволодіння мовою, і певні знання та уявлення про систему конкретною мовою [7, с. 42].

Міжкультурна комунікація припускає вміння співробітничати у взаємодії, спілкування 3 іншими людьми, готовність до спільної діяльності, формування партнерських відносин, стилю керівництва, знання способів вирішення конфліктних ситуацій, вироблення і знання норм поведінки, спілкування 3 протилежною підлогою й інше. Міжкультурна комунікація формується в процесі навчання у вищій 
школі шляхом включення в програму навчання іноземної мови культурознавчих, соціокультурного, культурологічного матеріалів країн мови, що вивчається.

Головною спільною метою мовної освіти $\epsilon$ підготовка учнів до активного і повноцінного співробітництва в сучасному полікультурному світі засобами мови, що вивчається. Нова наукова парадигма включає в міжкультурну комунікацію поняття «Міжкультурні компетенції», що увійшло до наукової літератури, i означає нові підходи до освітнього процесу.

В умовах динамічно мінливого сучасного світу відбувається оновлення вимог до фахівців, які повинні бути конкурентоспроможними в нових, постійно змінюваних видах діяльності, змін робочого місця. Молодь повинна вміти добре орієнтуватися в нових соціально-економічних структурах, ринкових відносинах, без яких вже неможливо уявити наше життя. Сформованість іншомовної комунікативної культури вказує на високий рівень засвоєння іноземної мови, який допомагає розширити межі пізнання, сприяє професійно-особистісному розвитку.

Знання та використання іноземної мови, як спосіб задоволення мотивів і здійснення цілей, характеризується як цілісна і зв’язна знакова освіта, комунікативна одиниця, реальна одиниця мовного спілкування, яка здатна в процесі цього спілкування висловити думку, бажання i почуття мовця (C.I. Бернштейн).

Іншомовні комунікативні дії включають комунікативний, когнітивний, діяльнісний та соціокультурний компоненти. Процес навчання передбачає поступове підвищення рівня суб'єктності фахівців у використанні іноземної мови від вузько навчальних до широкопрофільних комунікативних i професійних рівнів, шляхом ускладнення завдань модельованих мовних ситуацій, які використовуються в різних видах діяльності.

Більш досконалим видом використання іноземної мови є ускладнення розумової діяльності від репродуктивного до продуктивного, творчого, від простого відтворення готових думок, висловлених іншими людьми до здатності міркувати, аналізувати, приймати рішення.

Міжкультурне спілкування реалізує фізичні, матеріальні, інтелектуальні сили та інші можливості Людини для створення максимально ефективної комунікативної взаємодії, поєднуючи когнітивний, аналітичний (раціо), якісний (емоціо) i субстанціальний (інтуїціо) аспекти в цілісну єдність буття (Каменська О.Л.).

Методика викладання іноземних мов як наука має свою структуру, свої об'єкти і завдання. Методологія викладання іноземних мов проводиться $з$ позицій системно-діяльнісного підходу, змістовного наповнення 
навчальних дій, застосування міжтематичних зв'язків, розгляду проблемних ситуацій [4, с. 7].

Використання різних матеріалів і завдань передбачає розширення джерел інформації - друковані тексти, матеріали Інтернету, розробка завдань спрямованих на розвиток мовлення та мислення водночас, застосування засобів наочності, що дає можливість вибору самовизначення i самоконтролю. Видозмінюються мотиви засвоєння іноземної мови: від власне комунікативних (розуміння інших і самовираження засобами іноземної мови) до професійних, дослідницьких, проблемних. Різноманіття видів діяльності з використанням іноземної мови, підвищення рівня суб'єктності учня розширюють рамки навчальної діяльності, призводять до методичної інтерпретації навчальних дій; моделюються різні мовні ситуації, розробляються індивідуальні освітні програми, поступово ускладнюються вправи i завдання. Смислова організація своїх думок, переробка думок i підготовка їх до майбутнього вислову відбувається завдяки внутрішньому мовленню $[1$, с. 56]. Аналізуючи складності проблемної ситуації, готуючи свій виступ, студент вдається до внутрішнього формування думки, внутрішнього роздума, мобілізує свій досвід, знання, мовні засоби для точного виразу своїх думок, аргументації своєї позиції. За внутрішнім мовленням слід зовнішне мовлення іноземною мовою. Постійні розумові процеси підвищують якість оволодіння іноземною мовою, удосконалюючи механізми розумової діяльності.

Д.І. Ізаренков у своїй статті «Лінгвометодична інтерпретація навчального тексту» розглядає текст як вищу одиницю зв'язного мовлення, який отримав статус комунікативної одиниці, особливої одиниці навчання діяльності спілкування.

При вивченні іноземної мови потрібно пам'ятати про те, що тексти є основним носієм інформації, компонентом комунікації з різних видів спілкування: навчально-професійної, соціально-культурної та побутової.

Для формування міжкультурної комунікації в обсязі однієї або кількох тем (об'єктів) необхідно підбирати текстовий матеріал на рівні тематичних об'єднань, які можна називати «метатема».

Метатема - позначення систем, які служать для дослідження, вивчення або опису інших систем. «Метатема - це сукупність, безліч тем, що об'єднуються на основі єдності, тотожності аспектів розгляду позначених в них об'єктів (класів об'єктів)» [2, с. 91].

Позитивним у використанні цього підходу є те, що для вивчення предметного матеріалу може бути вичерпно представлений певний список метатем, на відміну від нескінченного різноманіття об'єктів; відбір матеріалу на рівні метатем надає навчальний матеріал в значно більш повному обсязі. 
Інтелектуальна компетентність - інтелектуальні ресурси, що забезпечують високий рівень досягнень в умовах реальної діяльності, інтегрують отримані в навчальному процесі знання, що сприяють уточненню, обгрунтуванню, оцінюванню, переробці, що з'являється при ефективному користуванні іноземною мовою. Сформована інтелектуальна компетентність забезпечує високий рівень когнітивних і метакогнітивних досягнень у процесі навчання, а також у ситуаціях реальної дійсності - вміння планувати, аргументувати, аналізувати, роздумувати, узагальнювати, передбачати, виконувати інші логічні операції [7, с. 3], а також здійснювати різні інтеркультурні комунікації від соціальноособистісних до професійних, наукових, дослідницьких.

Динамічні процеси, що відбуваються в світі, вплинули не тільки на всі сторони життя і діяльності сучасної людини, але й на мову, як засіб людського спілкування. Позначилися проблеми оптимізації мови, максимального поліпшення викладання та вивчення іноземних мов, що підвищують ефективність спілкування між ученими. Наука сучасного мовознавства створила і розробила теорію «мови для спеціальних цілей» (Language for Special Purposes - LSP). На підставі цієї теорії змодельований стиль наукового спілкування; стиль наукового викладу стає джерелом виявлення норми в процесі моделювання LSP в силу своєї мовної специфіки, покликаної адекватно довести до читача або слухача передану наукову інформацію.

\section{Література:}

1. Зимняя И.А. Индивидуально-психологические факторы и успешность научения речи на иностранном языке. Иностранные языки 8 школе. 2013. № 4. С. 55-64.

2. Изаренков Д.И. Лингвометрическая интерпретация учебного текста. Русский язык за рубежом. № 2-3, 1995. С. 90-95.

3. Каменская О. Л. Текст и коммуникация: Учеб. пособие для ин-тов и фак-тов иностр. яз. М.: Высш. шк., 1990. 152 с.

4. Ляховицкий М.В. О некоторых базисных категориях методики обучения иностранным языкам. Иностранные языки в школе. 2013. № 8. C. 4-10.

5. Національна доктрина розвитку освіти України у XX1 столітті: II Всеукраїнський з'їзд працівників освіти. К., 2002.

6. Тесленко В. На шляху до нової парадигми освіти. Іноземні мови в начальних закладах. 2007. № 3. С. 5-6.

7. Устименко О.М. Навчання іншомовного монологічного мовлення в аспекті компетентностного підходу. Іноземні мови. - 2013. № 1. С. 3-5. 